\title{
THE STUDY OF PROPERTIES OF MINCES IN BOILED SAUSAGES WITH FUNCTIONAL FOOD COMPOSITION USE
}

\author{
Ihor Strashynskiy \\ Department of Technology of Meat and Meat Products \\ National University of Food Technologies \\ 68 Volodumurska str., Kyiv, Ukraine, 01601 \\ sim2407@i.ua \\ Oksana Fursik \\ Department of Technology of Meat and Meat Products \\ National University of Food Technologies \\ 68 Volodumurska str., Kyiv, Ukraine, 01601 \\ fursikoksana@gmail.com \\ Vasil Pasichniy \\ Department of Technology of Meat and Meat Products \\ National University of Food Technologies \\ 68 Volodumurska str., Kyiv, Ukraine, 01601 \\ Pasww1@ukr.net \\ Andriy Marynin \\ Laboratory of Problem Research \\ National University of Food Technologies \\ 68 Volodumurska str., Kyiv, Ukraine, 01601 \\ a_marinin@ukr.net \\ Georgiy Goncharov \\ Department of Technology of Meat and Meat Products \\ National University of Food Technologies \\ 68 Volodumurska str., Kyiv, Ukraine, 01601 \\ GGI17@ukr.net
}

\footnotetext{
Abstract

The priority direction of innovative activity of meat-processing enterprises is a production of accessible goods of stable and high quality. The attainment of set aim is provided by introduction of diverse food additives (emulsifiers, stabilizers, stiffeners and so on) that replace the significant part of the main raw material for improvement of its functional-technological properties at creation of food systems.

The influence of elaborated functional food composition on functional-technological and structural-mechanical properties of minces in boiled sausages was studied. It was established, that its introduction into the content of meat minces improves the indices of water-binding ability by 3,5-5\% percents comparing with the control sample. Emulsifying ability in the studied samples increases on the average by $5 \%$, and emulsion steadiness by $22,5 \%$. It is conditioned by the ability of protein preparations and hydrocolloids, included in the composition together with meat proteins, to encapsulate the fat drops and to keep them during the whole technological process. Determination of the influence of elaborated functional mixture on structural-functional properties of minces demonstrated, that effective viscosity for the studied samples increased on the average by $48,5 \%$, and the index of extreme tension of the shift decreased on the average by $40,5 \%$.

The received results prove the perspective of replacement of the part of meat raw material (up to $30 \%$ ) by created composition and improvement of functional-technological and structural-mechanical properties of minces. It provides the stable high quality of ready goods and allows improve the effectiveness of production.

Keywords: minces of boiled sausages, protein-containing composition, functional-technological properties, effective viscosity, extreme tension of the shift. 


\section{Introduction}

Meat products are the significant part in the food structure of Ukrainian population [1]. The priority direction of innovative activity of meat-processing enterprises is a production of economically accessible goods of stable and high quality that are able to satisfy the low purchasing capacity of Ukrainian population. The attainment of set aim is provided by introduction of diverse food additives (emulsifiers, stabilizers, stiffeners and so on) that replace the significant part of the main raw material for improvement of its functional-technological properties (FTP) at creation of food systems [2].

The additives gain the special importance under conditions of modern manufacturing of meat products that is connected with wide use of protein preparations, polysaccharides and so on. It allows purposefully change the functional-technological characteristics of the food system and receive the necessary technological effect and significantly influences the color, taste and smell of goods $[3,4]$.

Under conditions of permanent growth of prices of food additives the producers of meat goods are interested in objective choice of trade forms and doses of their introduction for minimization of costs of manufacturing of meat products and stabilization of their quality, so in improvement of technological validity of the food additives use [5]. The analysis of researches [6] proves the advantages of the use of complex additives as ready mixture. It raises the effectiveness of production and facilitates technological process, provides the stable quality of ready product, helps to attain the needed technological effect and provide the necessary functional-technological (FTP), structural-mechanical (SMP) and organoleptic properties of ready goods.

The analysis of literary sources demonstrated that most scientific works are directed on the study of main properties of two-component systems and their influence on the production quality. It is known, that the presence of different substances (proteins, hydrocolloids, salts of organic and inorganic acids and other) even at insignificant concentrations essentially modifies the functional properties of these systems that substantially influences the quality of ready products $[3-5,7]$. Thus, prognostication of technological effect at introduction of one or another additive in the food product causes the necessary of study of complicated multi-component systems (for example, combination of hydrocolloids with protein preparations) and investigation of their influence on the quality of meat products as opposite to two- and three-component ones.

Substantiation of the expedience of the use of elaborated protein-containing functional food composition that includes rationally selected mixture of protein preparations, hydrocolloids with structure-forming nanocomposite (food additive E551) and determination of its influence on the properties of mince systems of boiled sausages is the actual direction of researches.

The aim of researches is the creation of meat mince systems with replacement of the main meat raw material by elaborated protein-containing FFC.

\section{Materials and Methods}

At the department of meat and meat products technology of the National university of food technologies (city Kyiv, Ukraine) were elaborated and studied the recipes of protein-containing functional food composition (FFC). It includes:

- protein of porcine skin, Belkaton-C95 - $35 \%$;

- soy isolate Pro Vo $500 \mathrm{U}-15 \%$;

- guar gum - $20 \%$;

- xanthan gum $-8 \%$;

- carboxymethyl cellulose - $15 \%$;

- dry lactoserum - $7 \%$;

- pyrogenic silica - 0,3\%.

The protein of animal origin of porcine skin Belkoton-C95 - enterprise-producer: "Scanflavour", country: Denmark. Soy isolate Pro Vo 500 U - Group of Companies "Protein. Technologies. Ingredients", Russia. Dry lactoserum - LTD “Tulchincky buttercheaseplant”, Ukraine. The countryproducer of carboxymethyl cellulose, xanthan gum is Fineland, CP Kelco enterprise, and guar gum - "Sarda Gums\&Chemicals", India. 
The studies $[8,9]$ established the rational degree of composition hydration at the level 1:20 that provides the necessary properties of gels. Hydration was carried out by water at temperature $10 \pm 2{ }^{\circ} \mathrm{C}$ with silica introduction in quantity $0,3 \%$ of the gel mass. There was used the silica, synthesized by the specialists of department of amorphous structures and structurally ordered oxides of the institute, named after A. A. Chuyko, NAS of Ukraine (city Kyiv, Ukraine) with specific area of surface $\mathrm{S}_{\text {bet }}=232 \mathrm{~m}^{2} / \mathrm{g}$, with correspondent middle radius of initial nanoparticles $5,88 \mathrm{~nm}$ and poured density $\rho_{0} \approx 22 \mathrm{~g} / \mathrm{cm}^{3}[10,11]$. The expedience of introduction of this food additive (E551) is proved by the researches of determination of its influence on the properties of milk proteins [12] and protein preparations $[8,9,13]$.

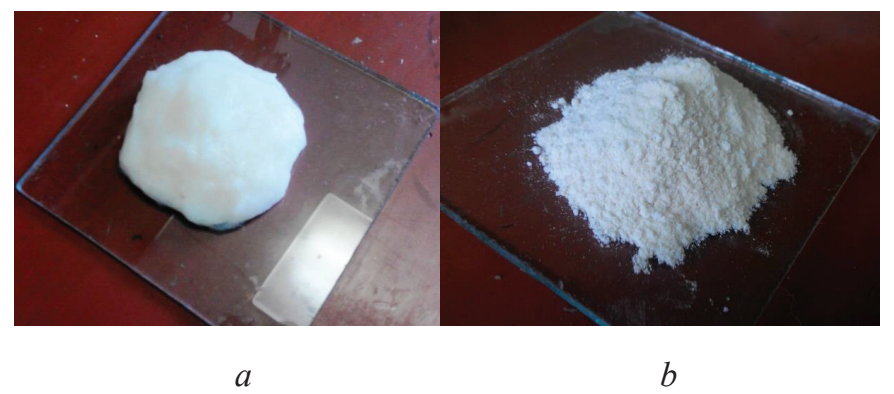

Fig. 1. Protein-containing functional food composition: $a$-hydrated; $b$-dry

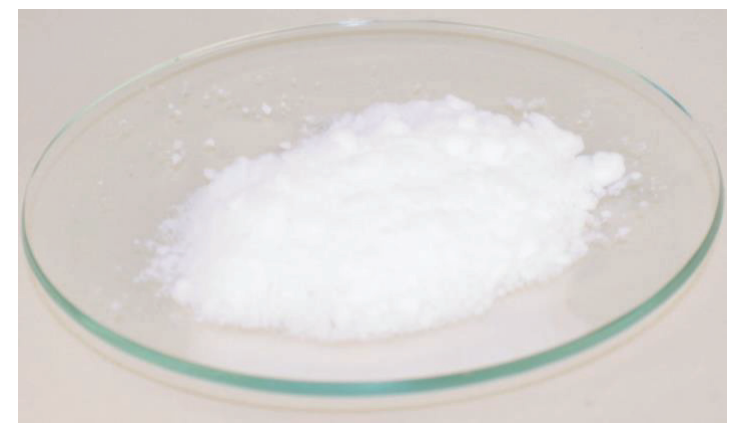

Fig. 2. Nanocomposite, silica (food additive E551)

The recipe of boiled sausages (of first quality) according TS U 15.1-20021369-005:2007 that includes: beef of second quality, semi-fatty pork, meat of bird (red chicken meat), lard (brisket), flour, blend, salt and spices was taken as a control. On its base were elaborated the recipes of studied samples of boiled sausages, in which the meat raw material was replaced by the correspondent quantity of hydrated FFC (20, 30 and $40 \%$ ). In the recipe № $110 \%$ of lard and $10 \%$ of beef of second quality was replaced by $20 \%$ of hydrated composition. For the recipe № $210 \%$ more of composition was additionally introduced instead of analogous quantity of chicken meat. For the studied samples according to the recipe № $310 \%$ more of red chicken meat was replaced by composition. The studied samples of meat minces were produced according to the technology that includes comminution of recipe components to the creation of homogenous mass, typical for boiled sausages [14]. The elaborated FFC was added at the stage of cuttering after salt fatless raw material, sodium nitrite (as $0,5 \%$ solution), phosphates with introduction of additional water in quantity $20 \%$ of the main raw material.

The main aspect of determination of expedience of replacement of meat raw material by protein-containing FFC is the determination of main parameters that condition FTP and SMP of received minces. The determination of these parameters was carried out according to the methods, given in [15].

The content of moisture was determined by the way of drying of the batch of product with following weighing and measuring of mass change. 


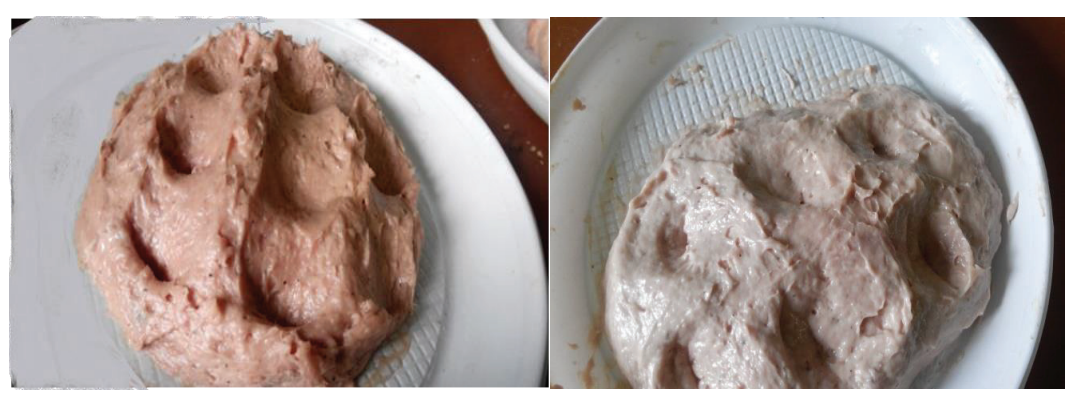

$a$

$b$

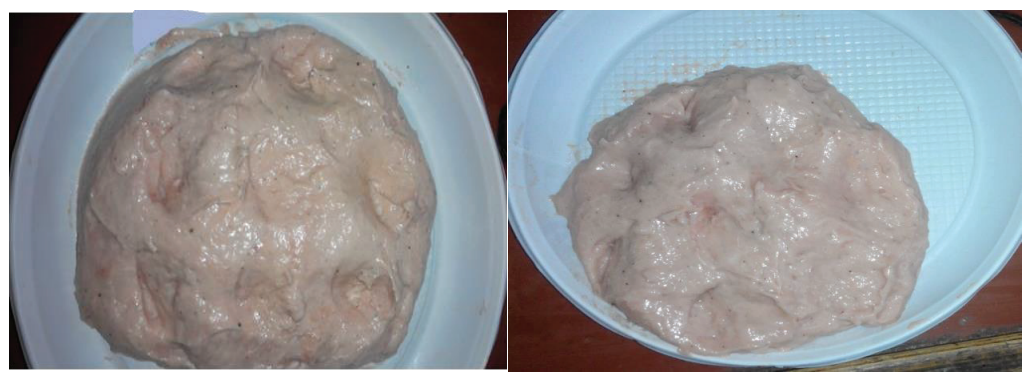

$c$

$d$

Fig. 3. Minces of boiled sausages: $a$ - control sample; $b$ - studied sample № 1 (with $20 \%$ of FFC); $c$-studied sample № 2 (with $30 \%$ of FFC); $d$ - studied sample № 3 (with $40 \%$ of FFC)

The method of determination of water-binding ability (WBA) is based on the measuring of area of moisture, separated from the batch with mass $300 \mathrm{mg}$ as the result of 10-minute pressing by weight with mass $1 \mathrm{~kg}$. For determination of plasticity the results, received at WBA determination by pressing were used. The determination of hydrogen ions concentration was carried out on pH-meter HI 98128 (firm-producer - Hanna Instruments, India) in aqueous extract of comminuted batch with hydration module 1:10 at 300-minute keeping.

The indices of emulsion steadiness and emulsifying ability were carried out by the measuring of oil that was separated in the process of centrifuging of preliminary prepared emulsion after heating at temperature $80^{\circ} \mathrm{C}$ and without heating respectively.

The study of effective viscosity and extreme tension of the shift of minces of boiled sausages was carried out at temperature $(10 \pm 2)^{\circ} \mathrm{C}$ on rotational viscometer by Volarovych RV-8M (Russia) [16]. The study provides two stages: I - measuring of empty glass (without product) for determination of bearings friction (error of measurement); II - with studied subject.

The absolute error of measuring was determined using Student criterion, reliable interval $\mathrm{P}=0,95$, number of reiterations in determinations $3-4$, number of parallel tests of studied samples -3 .

\section{Results}

WBA for the control sample is $92 \%$. It was established that FFC introduction into the mince of boiled sausages increases WBA of the sample, made according to the recipe № 1 by 4,9\% comparing with the control sample, according to the recipe № 2 by $4,8 \%$, and according to the recipe № 3 by $3,6 \%$. We can observe the partial decrease of this index at the increase of change of meat raw material by FFC. It is explained by a little lower WBA index for hydrated FFC that is $85,7 \pm 3,4 \%$ at hydration degree $1: 20$. But the components, included to the composition, were selected, taking into account the possibilities of synergetic interactions between them that allowed it together with meat proteins to bind and keep not only moisture, introduced at hydration but also the additional moisture, according to the recipe ratio.

The steadiness of emulsion for studied meat minces is within $48-49,5 \%$ and proves the advantages of FFC usage in recipes of boiled sausages. In model minces this index grows by $22,5 \%$ comparing with control sample. Emulsifying ability is $94-99,5 \%$ and increases comparing with 
studied sample for the recipe № 1 and № 2 by 5,8 \%, for the recipe № 3 by 3,7 \%. The high FTP of studied minces are grounded by the properties of ingredients, included in this composition.

The following stage was the study of structural-mechanical properties of minces and their comparison with control sample for determination of the influence of created composition on consistence.

The study of SMP testifies that with increase of the quantity of introduced composition the effective viscosity of meat mince decreases. Especially for the studied sample of the recipe № 1 by $19,5 \%$, recipe № 2 by 55,4 \%, recipe № 3 by 70,7 \% comparing with control. At the same time there takes place the decrease of index of extreme tension of the shift by $19,5 \%, 41,6 \%$ and $60,4 \%$ respectively. It is explained by the increase of quantity of dispersed medium that conditions the elasticity and liquidity of studied minces comparing with the control sample. FFC introduction modifies SMP and improves consistence, because the decrease of effective viscosity favors the receiving of more tender and juicy product.

The addition of silica (food additive E551) in FFC content improves FTP of the studied samples and favor the structure creation in mince systems due to interaction with protein preparations and meat protein that corresponds to the results, presented in the works $[8,9,12,13]$.

\section{Conclusions}

The rational combination of food additives in the composition of mixture with taking into account of the possible synergetic interactions allowed receive the stable matrix of meat system with encapsulated recipe components and improve FTP and SMP of the minces of boiled sausages. The received results testify to the attainment of set aim. The study of functional-technical and structural-mechanical properties of the model minces established the rational quantity of change of the meat raw material at the expense of introduction of $30 \%$ of hydrated protein-containing functional food additive.

As it is known, the use of individual additives significantly increases the complexity of technological process. At that it is possible the lowering of effectiveness of separate preparations at their incorrect combination and also the worsening of mince systems quality. The use of created functional food additive in technology of boiled sausages has the series of advantages: it increase of production effectiveness, facilitates technological process without changing the instrument-technological system; leads to minimization of costs of production and stable quality at the expense of improvement of FTP and SMP of the minces; allows attain the necessary technological effect.

In complex mixture the dosage of additives is calculated, taking into account their necessary amount for provision of optimal properties of meat systems and ready products. That is why at the use of functional compositions in recipes of boiled sausages it is not necessary to calculate and revise the dosage of all components, because the recommended dose is given, taking into account the concentration and properties of all components.

The use of additives gains the special importance under conditions of the modern production of meat goods, especially sausages, including boiled ones. It is conditioned by the fact that the meat with low FTP, including the one with deviations from classical development of autolytic processes (PSE - pale, soft, exudative; DFD - dark, firm, dry; RSE - red, soft, exudative) is often used at their production. The meat of technical additional flouring, meat raw material with high content of connective tissue is also used. The complex solution of the problem of low FTP of the raw material and increase of production economic effectiveness, exclusion of the defects of ready products is provided at the expense of using composition with rationally selected components and allows supply the population with accessible high-quality products.

The one more problem of population nourishment is a deficit of full value food protein (with balanced amino acid composition). The animal protein (for example, meat) is characterized with most favorable amino acids ratio. The replacement of significant part of meat raw material in recipe composition changes amino acid composition that can have both positive and negative results. As far as amino acid composition and assimilability of product are the important characteristics of biological value, their further study is necessary. 
For the final confirmation of expedience of replacement of the meat raw material by elaborated composition and its positive influence on the properties of meat products, the following stage of the work provides determination of the complex of indices in ready sausage goods.

\section{References}

[1] Skrypnyk, A. V., Rodyna, M. A., Volovodenko, L. V. (2014). Perspektyvy dosiahnennia svitovykh standartiv spozhyvannia miasa v Ukraini. Ekonomika ta upravlinnia natsionalnym hospodarstvom, $1,95-102$.

[2] Hollingworth, C. S. (2011). Hydrocolloids - How to choose? Brenntag Food \& Nutrition Europe, 1, 2-9.

[3] Pasichniy, V., Yushchenko, N., Mykoliv, I., Kuzmyk, U. (2015). Structure stabilization of fermented-milk pastes. Ukrainian Food Journal, 4 (3), 431-439.

[4] Prabhu, G. A., Doerscher, D. R., Hull, D. H. (2006). Utilization of pork collagen protein in emulsified and whole muscle meat products. Journal of Food Science, 69 (5), 388-392. doi: 10.1111/j.13652621.2004.tb10703.x

[5] Semenova, A. A. (2009). O tehnologicheskoy praktike primeneniya pischevyih dobavok v myasnoy promyishlennosti. Vse o myase, 1, 17-23.

[6] Mansvetova, E. V. (2008). Pischevyie polisaharidyi i ih ispolzovanie v myasnoy promyishlennosti. Myasnaya industriya, 12, 25-29.

[7] Marchetti, L., Andrés, S. C., Califano, A. N. (2014). Low-fat meat sausages with fish oil: Optimization of milk proteins and carrageenan contents using response surface methodology. Meat Science, 96 (3), 1297-1303. doi: 10.1016/j.meatsci.2013.11.004

[8] Pasichnyi, V. M., Strashynskyi, I. M., Fursik, O. P. (2015). Investigation of the emulsions based on functional food compositions containing protein. Technology Audit and Production Reserves, 3 (3 (23)), 52-55. doi: 10.15587/2312-8372.2015.44177

[9] Strashynskyi, I. M., Pasichnyi, V. M., Fursik, O. P. (2015). Reolohichni vlastyvosti hidratovanykh bilokvmisnykh funktsionalnykh kharchovykh kompozytsii. Novi rishennia v suchasnykh tekhnolohiiakh, 62 (1171), 166-170.

[10] Market Attitude Research Services, Australian Community Attitudes about Nanotechnology 2005-2009 (2009). Australia: Department of Industry, Innovation, Science and Research.

[11] Appropriate Risk Governance Strategies for Nanotechnology Applications in Food and Cosmetics (2009). Siwtzerland, Geneva: International Risk Governance Council, Policy Brief, 44.

[12] Ivanov, S., Pasichniy, V., Strashinskiy, I., Marinin, A., Fursik, O., Krepak, V. (2014). Polufabrikatyi iz myasa indeyki s ispolzovaniem teksturoformiruyuschih napolniteley. Himiya i tehnologiya pischi, 2 (48), 25-33.

[13] Pasichniy, V. M., Marynin, A. I., Moroz, O. O., Heredchuk, A. M. (2015). Development of combined protein-fat emulsions for sausage and semifinished products with poultry meat. Eastern-European Journal of Enterprise Technologies, 1 (6 (73)), 32-38. doi: 10.15587/1729-4061.2015.36232

[14] Rogov, I. A., Zharinov, A. I., Tekuteva, L. A., Shepel, T. A. (2009). Biotehnologiya myasa i myasoproduktov. Moscow: DeLi print, 296.

[15] Antipova, L. V., Glotova, I. A., Rogov, I. A.; Kurkina, N. V. (Ed.) (2001). Metodyi issledovaniya myasa i myasnyih produktov. Moscow: Kolos, 376.

[16] Machihin, Yu. A., Gorbatov, A. S., Maksimov, A. S. et. al. (1990). Reometriya pischevogo syirya i produktov. Moscow: Agropromizdat, 271. 